Article

\title{
Synthesis and Promotion of the Osteoblast Proliferation Effect of Morroniside Derivatives
}

\author{
Hua Han, ZhengQing Li, Na Qu, Si Chen and PeiLiang Dong * \\ Key Laboratory of Chinese Materia Medica, Ministry of Education, Heilongjiang University of Chinese \\ Medicine, Harbin 150040, China; hh7551@163.com (H.H.); lizhengqing1125@163.com (Z.L.); \\ Qu399127818@163.com (N.Q.); m13945033486@163.com (S.C.) \\ * Correspondence: peiliang_D@163.com
}

Received: 2 April 2018; Accepted: 7 June 2018; Published: 11 June 2018

\begin{abstract}
Sambucus williamsii Hance has been used in fractures for thousands of years, but research on its active components, such as morroniside, until now had not been carried out. In this study, morroniside was taken as the leading compound, and fourteen derivatives were synthesized. The promotion of osteoblast proliferation effect of the derivatives was evaluated on MC3T3-E1 cells. Five derivatives $(2,3,4,5$, and $\mathbf{1 4})$ showed a good proliferation effect on MC3T3-E1 cells, and their promoted expression effects on OC (Osteocalcin) and ALP (Alkaline phosphatase) in MC3T3-E1 cells were measured. Compound 3 was shown to have the strongest proliferation effect $\left(\mathrm{EC}_{50}=14.78 \pm 1.17 \mu \mathrm{g} / \mathrm{mL}\right)$ and to significantly promote the expression of OC and ALP.
\end{abstract}

Keywords: morroniside; derivatization; osteoblast proliferation effect; MC3T3-E1

\section{Introduction}

Fracture is one of the most common clinical diseases and often causes substantial damage to a patient's quality of life [1]. Without proper care and recovery, it can cause irreversible damage to the patient [2]. In recent years, with the increase in the elderly population, the incidence of osteoporosis has become the seventh most common affliction in the world, and about $80 \%$ of elderly people have different degrees of osteoporosis [3,4]. Due to osteoporosis in patients with osteopenia, bone strength decreases, bone fragility increases, and the probability of fracture greatly increases [5]. Moreover, the healing process of osteoporosis fracture is long, and clinical efficacy is extremely low, seriously affecting the daily life of the elderly [6].

Currently, conservative treatment of osteoporotic fracture in the elderly has become one of the most commonly used clinical methods [7]. The main drugs for the treatment of fractures in clinics are anti-inflammatory drugs, analgesics, and drugs that promote fracture healing [8,9]. Sambucus williamsii Hance has been used in the clinical treatment of various types of fractures for thousands of years, with short course, rapid recovery, and high efficacy [10]. Previous studies have shown that morroniside is the main component of $S$. williamsii Hance [11,12], which can lower serum calcium, promote the deposition of calcium salts, promote collagen synthesis, improve the quality of callus, and has great potential for clinical applications [13-15]. However, our previous studies have shown that morroniside, when used alone, weakly promotes the proliferation of MC3T3-E1 cells (the proliferation rate is about $20 \%$ in $24 \mathrm{~h}$ with $62.5 \mu \mathrm{g} / \mathrm{mL}$ morroniside) $[15,16]$. In addition, the poor solubility, the rapid metabolism in the body, and the low bioavailability of morroniside has limited its clinical application, so morroniside cannot be developed as a clinical drug [17].

In this study, we used morroniside as a leading compound to obtain different derivatives to obtain a compound with more value and a strong promoting effect on fracture healing. Two of the derivatives are new compounds (12 and $\mathbf{1 3})$. 


\section{Results and Discussions}

\subsection{Preparations of Morroniside Derivatives}

Compound 1 was synthesized by hydrolyzing morroniside in a $20 \%$ hydrochloric acid aqueous solution at $50^{\circ} \mathrm{C}$ for $1 \mathrm{~h}$, in a yield of $35 \%$ (Figure 1 ).

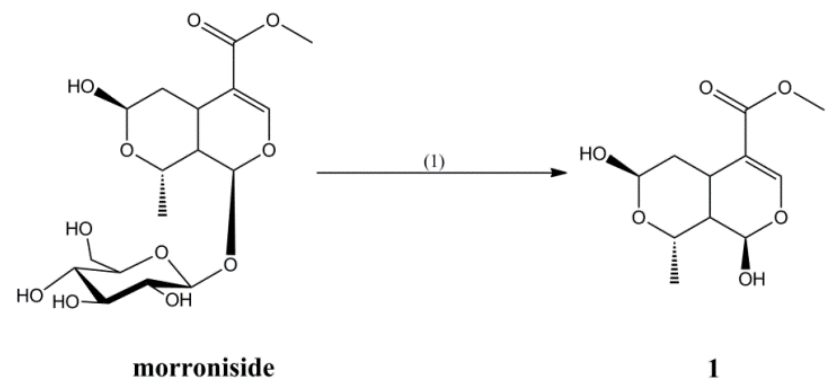

Figure 1. Synthesis of Compound 1. (1) $20 \% \mathrm{HCl}, 50^{\circ} \mathrm{C}, 1 \mathrm{~h}$.

Compounds 2-9 were synthesized by reacting morroniside with different alcohols at room temperature in the presence of concentrated nitric acid as a catalyst for $30 \mathrm{~min}$, for yields of $23 \%, 55 \%$, $26 \%, 51 \%, 24 \%, 48 \%, 24 \%$, and $49 \%$, respectively (Figure 2 ).

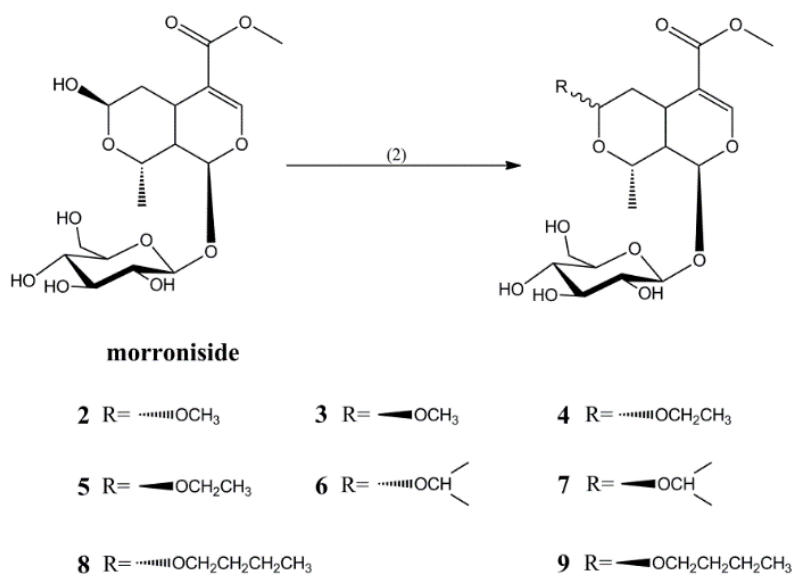

Figure 2. Synthesis of Compounds 2-9. (2) RH, concentrated nitric acid, r.t., $30 \mathrm{~min}$.

Compounds 10-12 were synthesized by reacting morroniside with acetic anhydride at different temperatures in methanol for $1 \mathrm{~h}$, for yields of $22 \%, 40 \%$, and $45 \%$, respectively (Figure 3 ).

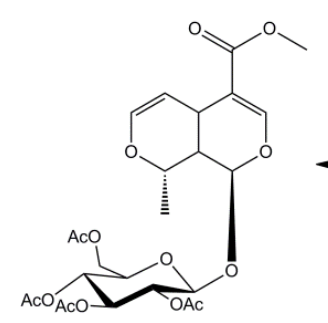

12

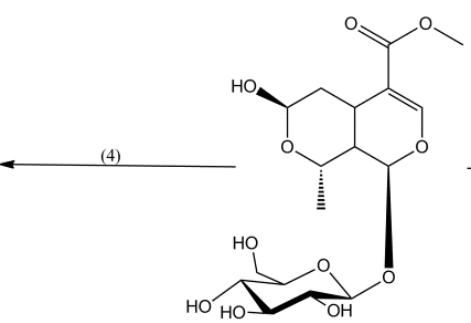

morroniside

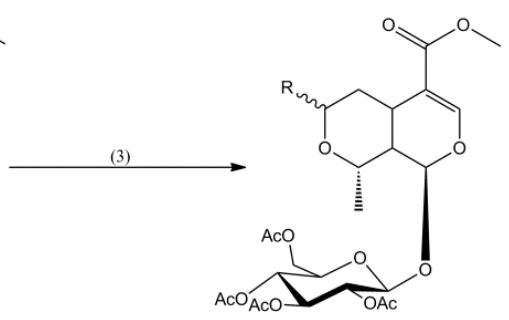

$10 \mathrm{R}=\ldots \ldots+\cdots \mathrm{OCH}_{3}$

Figure 3. Synthesis of Compounds 10-12. (3) $\mathrm{MeOH}$, acetic anhydride, $80{ }^{\circ} \mathrm{C}, 1 \mathrm{~h}$. (4) $\mathrm{MeOH}$, acetic anhydride, $200{ }^{\circ} \mathrm{C}, 1 \mathrm{~h}$. 
Compounds 13 and 14 were synthesized as monoterpene alkaloids derivatives with different primary amines, in yields of $32 \%$ and $46 \%$, respectively (Figure 4 ).



Figure 4. Synthesis of Compounds 13 and 14. (5) Methylamine ethanol solution, $10^{\circ} \mathrm{C}, 3 \mathrm{~h}$. (6) $\mathrm{C}_{2} \mathrm{H}_{5} \mathrm{OH}$, HOAc-NaAc buffer solution, $\beta$-glucosidase, $50{ }^{\circ} \mathrm{C}, 3 \mathrm{~h}$.

\subsection{Cell Viability Assay}

The MTT assay was used to evaluate the proliferation effect of the morroniside derivatives on MC3T3-E1 cells, and their values $\mathrm{EC}_{50}$ are shown in Table 1. Five compounds (2, 3, 4, 5, and 14) promoted proliferation on MC3T3-E1 cells $\left(\mathrm{EC}_{50}<500\right)$ more strongly than did the other derivatives. Among these five compounds, Compound 3 showed the strongest proliferation effect on MC3T3-E1 cells, Compound 14 showed the weakest, and Compounds 2, 5, and 4 showed a medium effect.

Table 1. $\mathrm{EC}_{50}$ values of derivatives promoting proliferation on MC3T3-E1 cells (mean $\pm \mathrm{SD}$ ), $n=5$.

\begin{tabular}{cccc}
\hline Compound & $\mathrm{EC}_{\mathbf{5 0}}(\boldsymbol{\mu \mathrm { g } / \mathrm { mL } )}$ & Compound & $\mathrm{EC}_{\mathbf{5 0}}(\boldsymbol{\mu \mathrm { g }} / \mathrm{mL})$ \\
\hline $\mathbf{1}$ & $2042 \pm 3.310$ & $\mathbf{8}$ & $1068 \pm 3.029$ \\
$\mathbf{2}$ & $118.2 \pm 2.073$ & $\mathbf{9}$ & $656.0 \pm 2.817$ \\
$\mathbf{3}$ & $14.78 \pm 1.170$ & $\mathbf{1 0}$ & $961.6 \pm 2.983$ \\
$\mathbf{4}$ & $434.2 \pm 2.638$ & $\mathbf{1 1}$ & $1022 \pm 3.009$ \\
$\mathbf{5}$ & $164.4 \pm 2.216$ & $\mathbf{1 2}$ & $927.0 \pm 2.967$ \\
$\mathbf{6}$ & $1342 \pm 3.128$ & $\mathbf{1 3}$ & $637.2 \pm 2.804$ \\
$\mathbf{7}$ & $1028 \pm 3.012$ & $\mathbf{1 4}$ & $307.8 \pm 2.488$ \\
\hline
\end{tabular}

The activity of morroniside is conspicuously decreased when morroniside is hydrolyzed into aglycone (Compound 1). In addition, iridoids cannot keep in a form of prototype drug in the human body due to rapid metabolism [18], possibly resulting in low activity of morroniside in vivo.

In the case of acetylation into Compounds 10, 11, and 12, morroniside gains less bioactivity. Nonetheless, the acetyl group can be removed through metabolism of enzymes, thereby releasing the morroniside and postponing its metabolism, consequently prolonging drug action time [19]. Therefore, the bioactivity of acetylated morroniside still needs to be further researched.

The activity of morroniside, to some extent, is likely to be enhanced when morroniside is alkylated at C-7 position, and enhancement only occurs when substituted with methyl or ethyl. Research also shows that the activity of morroniside will be gradually decreased with the increasing number of carbon atoms on the alkyl chain. When the number of carbon atoms on the alkyl chain exceeds 3 , the activity of alkylated morroniside will be far lower than that of morroniside itself. Moreover, the activity will be tremendously enhanced if the substituent is in $\beta$ configuration rather than $\alpha$ configuration.

Research on alkaloids has been extensively carried out owing to the diverse structural characteristics and pharmacological actions of such substance [20]. In this study, when aglycone is transformed into pyridine monoterpene alkaloids derivatives (Compound 13), the pharmacological activity is significantly enhanced, which proves that alkaloids have massive pharmacological potential. 
Besides, the activity of morroniside is conspicuously stimulated when its mother nuclear structure is broken, which transforms morroniside into Compound 14. Furthermore, the stability of alkaloids is stronger than that of morroniside because glycosidic linkage and hemiacetal structure are absent in Compounds 13 and 14. It is speculated that the metabolism of alkaloids probably takes much longer time than that of morroniside and its action efficacy is likely to be further extended as a consequence.

\subsection{Activities of OC and ALP Assay}

Osteocalcin (OC) and alkaline phosphatase (ALP) are two substances secreted by osteoblasts [21,22] and can promote the deposition of bone salt. The expression of OC and ALP can reflect the rate of fracture healing [23]. Therefore, in this study, we measured the effects of five compounds on the expressions of OC and ALP in osteoblasts, and the results are shown in Figure 5.


Figure 5. Promotion effect of $90 \mu \mathrm{g} / \mathrm{mL}$ of $\mathbf{2}, \mathbf{3}, \mathbf{4}, \mathbf{5}$, and 14 on OC and ALP expression in MC3T3-E1 cells: (A) OC levels; and (B) ALP activities. All values are represented as mean $\pm \mathrm{SD}, n=5$. ${ }^{* *} p<0.01$ versus the control. ${ }^{* * *} p<0.001$ versus the control.

As can be seen in the figure, the above-mentioned five derivatives are able to elevate the expression OC and ALP, in significant contrast to the blank group $(p<0.05)$. Among the five derivatives, Compound 3 stands out as possessing remarkable efficacy superior to the other four $(p<0.05)$. It is shown that Compound 3 has the best activity in elevating the expression OC and ALP.

\section{Materials and Methods}

\subsection{General}

NMR spectra were performed on a Bruker DRX-400 NMR spectrometer at $400 \mathrm{MHz}$ using $\mathrm{CD}_{3} \mathrm{OD}$ as solvent in Zhengzhou University. The purity of morroniside and the derivatives were checked on a Waters e2695 liquid chromatograph equipped with 2424 ELS detector and 2998 PDA detector. GF254 silica plate was purchased from Qingdao Haiyang Chemical Co. Ltd. (Qingdao, China). The Elisa kits of OC (H152) and ALP (A059-2) were purchased from Nanjing Jiancheng Bioengineering Institute (Nanjing, China). All the chemical reagents were purchased from Sinopharm Chemical Reagent Co., Ltd. (Shanghai, China). The morroniside was extracted and purified in the medicinal chemistry department, Heilongjiang University of Chinese Medicine.

\subsection{Synthesis}

\subsubsection{Synthesis of Compound 1}

An amount of $0.1 \mathrm{~g}$ of morroniside was dissolved with $2 \mathrm{~mL}$ of a $20 \%$ hydrochloric acid solution, and the mixture was heated for $1 \mathrm{~h}$ at $50{ }^{\circ} \mathrm{C}$. After this mixture was cooled to room temperature, saturated sodium bicarbonate was added to remove the hydrochloric acid, the solvent was recovered in vacuum, and the residue was purified by silica gel column chromatography and eluted with petroleum ether-ethyl acetate (5:1) to obtain Compound $\mathbf{1}(21.1 \mathrm{mg}$, 35\% yield). 
The ${ }^{1} \mathrm{H}-\mathrm{NMR}$ and ${ }^{13} \mathrm{C}-\mathrm{NMR}$ results of Compound $\mathbf{1}$ are consistent with $\beta$-morroniside aglycone, so it was concluded that Compound $\mathbf{1}$ is $\beta$-morroniside aglycone [24].

\subsubsection{Synthesis of Compounds $\mathbf{2 - 9}$}

An amount of $0.1 \mathrm{~g}$ of morroniside was dissolved with $2 \mathrm{~mL}$ of different alcohols (methanol, ethanol, isopropanol, and $n$-butanol), and $0.1 \mathrm{~mL}$ of concentrated nitric acid was added. This mixture was stirred for $30 \mathrm{~min}$ at room temperature. After the reaction, moderate saturated sodium bicarbonate was added to remove the concentrated nitric acid, the solvent was recovered in vacuum, and the residue was purified by silica gel column chromatography and eluted with dichloromethane-methanol (16:1) to obtain Compounds 2 ( $23.8 \mathrm{mg}, 23 \%$ yield), 3 ( $56.9 \mathrm{mg}, 55 \%$ yield), 4 ( $27.8 \mathrm{mg}, 26 \%$ yield), 5 (54.5 mg, 51\% yield), 6 (26.5 mg, 24\% yield), 7 (53.0 mg, $48 \%$ yield), 8 (27.3 mg, 24\% yield), and 9 (55.8 $\mathrm{mg}, 49 \%$ yield).

The ${ }^{1} \mathrm{H}-\mathrm{NMR}$ and ${ }^{13} \mathrm{C}-\mathrm{NMR}$ of Compounds 2-9 are consistent with those reported in the previous study. However, it is worth noting that, if the configuration at C-7 is $\alpha$, the chemical shift of C-5 is more than 30, and C-8 is more than 70; if the configuration at C-7 is $\beta$, the chemical shift of C-5 is between 25 and 29, and C- 8 is between 62 and 66 [25].

\subsubsection{Synthesis of Compounds $\mathbf{1 0}$ and $\mathbf{1 1}$}

An amount of $0.1 \mathrm{~g}$ of morroniside was dissolved with $2 \mathrm{~mL}$ of methyl alcohol, and $2 \mathrm{~mL}$ of acetic anhydride was added. The mixture was refluxed for $1 \mathrm{~h}$ at $80^{\circ} \mathrm{C}$. The solvent was recovered in vacuum, and the residue was purified by silica gel column chromatography and eluted with petroleum ether-ethyl acetate (3:1) to obtain Compounds 10 ( $31.9 \mathrm{mg}, 22 \%$ yield) and $\mathbf{1 1}$ (58.0 mg, 40\% yield).

The ${ }^{1} \mathrm{H}-\mathrm{NMR}$ and ${ }^{13} \mathrm{C}-\mathrm{NMR}$ of Compounds $\mathbf{1 0}$ and $\mathbf{1 1}$ are consistent with those reported in the previous study, so it was concluded that Compounds $\mathbf{1 0}$ and $\mathbf{1 1}$ are $7 \alpha$-methoxy tetraacethyl morroniside and $7 \beta$-methoxy tetraacethyl morroniside, respectively [26].

\subsubsection{Synthesis of Compound 12}

An amount of $0.1 \mathrm{~g}$ of morroniside was dissolved with $2 \mathrm{~mL}$ of methyl alcohol, and $2 \mathrm{~mL}$ of acetic anhydride was added. The mixture was refluxed for $1 \mathrm{~h}$ at $200^{\circ} \mathrm{C}$. The solvent was recovered in vacuum, and the residue was purified by silica gel column chromatography and eluted with petroleum ether-ethyl acetate (3:1) to obtain Compound 12 (61.6 mg, 45\% yield).

6,7-double bond tetraacethyl morroniside (12): white powder; ${ }^{1} \mathrm{H}-\mathrm{NMR}\left(400 \mathrm{MHz}, \mathrm{CD}_{3} \mathrm{OD}\right)$ 8: 1.44 $(3 \mathrm{H}, \mathrm{d}, J=6.9 \mathrm{~Hz}, \mathrm{H}-10), 1.97\left(3 \mathrm{H}, \mathrm{s}, 6^{\prime}-\mathrm{CH}_{3}\right), 2.0(1 \mathrm{H}, \mathrm{m}, \mathrm{H}-9), 2.01,2.01,2.04$ (each $3 \mathrm{H}, \mathrm{s}, 3^{\prime}, 4^{\prime}$ and $\left.2^{\prime}-\mathrm{CH}_{3}\right), 3.41(1 \mathrm{H}, \mathrm{m}, \mathrm{H}-5), 3.71(3 \mathrm{H}, \mathrm{s}, \mathrm{H}-12), 3.92\left(1 \mathrm{H}, \mathrm{m}, \mathrm{H}-2^{\prime}\right), 4.14\left(1 \mathrm{H}, \mathrm{dd}, J=2.5 \mathrm{~Hz}, 12.3 \mathrm{~Hz}, \mathrm{H}-6^{\prime} \mathrm{a}\right)$, $4.18\left(1 \mathrm{H}, \mathrm{o}, \mathrm{H}-5^{\prime}\right), 4.31\left(1 \mathrm{H}, \mathrm{dd}, J=4.9 \mathrm{~Hz}, 17.3 \mathrm{~Hz}, \mathrm{H}-6^{\prime} \mathrm{b}\right), 4.69(1 \mathrm{H}, \mathrm{dt}, J=1.6 \mathrm{~Hz}, 6.2 \mathrm{~Hz}$, $\mathrm{H}-6), 4.96\left(1 \mathrm{H}, \mathrm{dd}, J=8.1 \mathrm{~Hz}, 9.7 \mathrm{~Hz}, \mathrm{H}-4^{\prime}\right), 5.03(1 \mathrm{H}, \mathrm{t}, J=6.9 \mathrm{~Hz}, \mathrm{H}-8), 5.15\left(1 \mathrm{H}, \mathrm{d}, J=8.1 \mathrm{~Hz}, \mathrm{H}-1^{\prime}\right)$, $5.33\left(1 \mathrm{H}, \mathrm{dd}, J=9.5 \mathrm{~Hz}, 19.0 \mathrm{~Hz}, \mathrm{H}-3^{\prime}\right), 5.40(1 \mathrm{H}, \mathrm{d}, J=8.6 \mathrm{~Hz}, \mathrm{H}-1), 6.30(1 \mathrm{H}, \mathrm{dd}, J=2.3 \mathrm{~Hz}, 6.1 \mathrm{~Hz}, \mathrm{H}-7)$, $7.48(1 \mathrm{H}, \mathrm{s}, \mathrm{H}-3) ;{ }^{13} \mathrm{C}$ NMR $\left(100 \mathrm{MHz}, \mathrm{CD}_{3} \mathrm{OD}\right) \delta: 19.5,20.5,20.6,20.6,20.6,31.0,39.0,51.9,62.9,69.9$, $72.5,73.1,74.1,74.8,96.5,98.7,103.8,110.3,144.1,153.2,168.7,171.1,171.3,171.6,172.3$; ESI-MS $m / z$ $557[\mathrm{M}+\mathrm{H}]^{+}$(calcd for $\mathrm{C}_{25} \mathrm{H}_{32} \mathrm{O}_{14}$ ).

\subsubsection{Synthesis of Compound $\mathbf{1 3}$}

An amount of $0.1 \mathrm{~g}$ of morroniside was dissolved with $2 \mathrm{~mL}$ of a methylamine alcohol solution, and the mixture was stirred for $3 \mathrm{~h}$ at $10{ }^{\circ} \mathrm{C}$. The solvent was recovered in vacuum, and the residue was purified by silica gel column chromatography and eluted with petroleum ether-ethyl acetate (1:1) to obtain Compound 13 (20.3 mg, 32\% yield).

2-N-Methyl morroniside aglycone (13): white powder; ${ }^{1} \mathrm{H}-\mathrm{NMR}\left(400 \mathrm{MHz}, \mathrm{CD}_{3} \mathrm{OD}\right) \delta: 1.30$ $(3 \mathrm{H}, \mathrm{d}, J=6.5 \mathrm{~Hz}, \mathrm{H}-10), 1.50(1 \mathrm{H}, \mathrm{m}, \mathrm{H}-9), 2.40(2 \mathrm{H}, \mathrm{m}, \mathrm{H}-6), 2.93(1 \mathrm{H}, \mathrm{m}, \mathrm{H}-5), 3.12\left(3 \mathrm{H}, \mathrm{s}, \mathrm{N}-\mathrm{CH}_{3}\right)$, $3.67(3 \mathrm{H}, \mathrm{s}, \mathrm{H}-12), 4.16(1 \mathrm{H}, \mathrm{dd}, J=6.5 \mathrm{~Hz}, 13.9 \mathrm{~Hz}, \mathrm{H}-8), 4.72(1 \mathrm{H}, \mathrm{d}, J=2.2 \mathrm{~Hz}, \mathrm{H}-7), 5.10(1 \mathrm{H}, \mathrm{s}, \mathrm{H}-1)$, 
7.29 (1H, s, H-3); ${ }^{13} \mathrm{C}-\mathrm{NMR}\left(100 \mathrm{MHz}, \mathrm{CD}_{3} \mathrm{OD}\right)$ 8: 19.4, 24.9, 34.2, 39.2, 40.8, 51.4, 71.0, 80.4, 87.5, 104.7, 144.1, 169.9; ESI-MS $m / z 258[\mathrm{M}+\mathrm{H}]^{+}$(calcd for $\mathrm{C}_{12} \mathrm{H}_{19} \mathrm{NO}_{5}$ ).

\subsubsection{Synthesis of Compound $\mathbf{1 4}$}

An amount of $0.1 \mathrm{~g}$ of morroniside was dissolved with $0.5 \mathrm{~mL}$ of an ethanol solution, and $5 \mathrm{~mL}$ of HOAc-NaOAc buffer solution ( $\mathrm{pH} 5$ ) and $0.1 \mathrm{~g}$ of $\beta$-glucosidase were added. The mixture was reacted for $3 \mathrm{~h}$ at $50{ }^{\circ} \mathrm{C}$. The solvent was recovered in vacuum, and the residue was purified by silica gel column chromatography and eluted with petroleum ether-ethyl acetate (5:1) to obtain Compound 14 (20.5 mg, 46\% yield).

The ${ }^{1} \mathrm{H}-\mathrm{NMR}$ and ${ }^{13} \mathrm{C}-\mathrm{NMR}$ of Compound $\mathbf{1 4}$ are consistent with those reported in the previous study, so it was concluded that Compound $\mathbf{1 4}$ is 5-(1'-hydroxyethyl) nicotinic acid methyl ester [27].

\subsection{Biological Assays}

The MC3T3-E1 cell line was obtained from Procell (Wuhan, China) and was grown in DMEM medium supplemented with $10 \%$ fetal bovine serum and a $1 \%$ penicillin-streptomycin solution.

The cell viability was evaluated using an MTT assay. The cells were plated in a 96-well plate with $100 \mu \mathrm{L}$ in each well $\left(1 \times 10^{4}\right.$ cells/well $)$ and then incubated for $24 \mathrm{~h}$ at $37^{\circ} \mathrm{C}$. The cells were then exposed to different concentrations $(100,10,1$, and $0.1 \mu \mathrm{g} / \mathrm{mL})$ of the derivatives and incubated for another $24 \mathrm{~h}$, and $20 \mu \mathrm{L}$ MTT regents $(5 \mathrm{mg} / \mathrm{mL})$ were subsequently added to each well, which was followed by incubation for $4 \mathrm{~h}$. The medium was removed, and $100 \mu \mathrm{L}$ of DMSO was added to each well, which were then shaken for $10 \mathrm{~min}$. The absorbance was measured by a microplate reader at a wavelength of $490 \mathrm{~nm}$. Control wells received only the medium without the derivatives. Each derivative concentration had five replicates. The cell viability was calculated using the following formula:

$$
\text { cell viability }(\%)=\left(\mathrm{A}_{\text {Sample }} / \mathrm{A}_{\text {Control }}-1\right) \times 100 \% \text {. }
$$

All results are expressed as mean \pm SD. All figures were illustrated using Prism 7 (SOFTHEAD, Shenzhen, China). Statistical analysis was carried out with SPSS 24 software (STRONG-VINDA, Beijing, China).

\subsection{Activities of OC and ALP Assays}

The Elisa kits of OC (H152) and ALP (A059-2) were purchased from Nanjing Jiancheng Bioengineering Institute (Nanjing, China).

The cells were plated on a 12-well plate with $1000 \mu \mathrm{L}$ in each well $\left(1 \times 10^{4}\right.$ cells/well $)$ and then incubated for $24 \mathrm{~h}$ at $37^{\circ} \mathrm{C}$. The cells were then exposed to compound 2, 3, 4, 5, and 14 in $90 \mu \mathrm{g} / \mathrm{mL}$ amounts, and incubated for three days. The cells and the medium were transferred to a $1.5 \mathrm{~mL}$ centrifuge tube, frozen and thawed three times, then placed in an ice box, and broken by an ultrasonic protein breaker. According to the ELISA kit instructions, $5 \mu \mathrm{L}$ of double distilled water (blank), $5 \mu \mathrm{L}$ of a $0.1 \mathrm{mg} / \mathrm{mL}$ phenol standard application solution (standard), and $5 \mu \mathrm{L}$ of derivative solution (measurement) were added. Afterwards, $50 \mu \mathrm{L}$ of buffer and matrix solution each were added, and the mixture was then placed in a $37^{\circ} \mathrm{C}$ water bath for $15 \mathrm{~min}$. An amount of $150 \mu \mathrm{L}$ of a chromogenic agent was added, and the OD (optical density) values were measured at $520 \mathrm{~nm}$.

\section{Conclusions}

Serial morroniside derivatives were synthesized, and their proliferation effects on MC3T3-E1 cells were evaluated in vitro. From the above studies, we can draw the following conclusions: (1) A series of products with alkylation at the C-7 position was synthesized by a new method. Compared with previous iodine catalysis [22], this synthetic method is more secure and economical and simplified the post-processing program. (2) Among the morroniside derivatives, Compounds 2, 3, 4, 5, and 14 had 
strong proliferation effects on MC3T3-E1 cells. Among them, Compound 3 exhibited the strongest effect. (3) The introduction of methyl, such as in Compounds 2 and 3, at Position 7 improved the proliferation effect on MC3T3-E1 cells. However, with the extension of the carbon chain, the activity decreases gradually. (4) With substitution with beta configuration at Position 7, the effect of the proliferation is higher than the alpha configuration substitution, such as Compounds 2, 3, 4, and 5 . (5) Acetylation in morroniside did not affect the proliferation effect on MC3T3-E1. (6) Transformation into the $\mathrm{N}$-containing derivative (Compound 14) slightly increases the effect, but this effect is still less substantial than the alkylation derivatives (Compounds 2 and $\mathbf{3}$ ).

Author Contributions: H.H. and P.D. conceived and designed the experiments; N.Q. and S.C. performed the experiments; Z.L. analyzed the data; H.H. contributed reagents/materials/analysis tools and Z.L. wrote the paper.

Funding: This research was funded by [Education Department of Heilongjiang Province] grant number [1153G038] and [Heilongjiang University of Chinese Medicine] grant number [B201003].

Conflicts of Interest: The authors declare no conflict of interest.

\section{References}

1. Marsell, R.; Einhorn, T.A. The Biology of fracture healing. Inj.-Int. J. Care Inj. 2011, 42, 551-555. [CrossRef] [PubMed]

2. Kanis, J.A.; Odén, A. A systematic review of hip fracture incidence and probability of fracture worldwide. Osteoporos. Int. J. Establ. Result Cooper. Eur. Found. Osteoporos. Natl. Osteoporos. Found. USA 2012, 23, 2239-2256. [CrossRef] [PubMed]

3. Boonen, S.; Reginster, J.Y.; Kaufman, J.M.; Lippuner, K.; Zanchetta, J.; Langdahl, B.; Rizzoli, R.; Lipschitz, S.; Dimai, H.P.; Witvrouw, R. Fracture risk and zoledronic acid therapy in men with osteoporosis. N. Engl. J. Med. 2012, 367, 1714-1723. [CrossRef] [PubMed]

4. Ensrud, K.E.; Ewing, S.K.; Taylor, B.C.; Fink, H.A.; Stone, K.L.; Cauley, J.A.; Tracy, J.K.; Hochberg, M.C.; Rodondi, N.; Cawthon, P.M. Frailty and Risk of Falls, Fracture, and Mortality in Older Women: The Study of Osteoporotic Fractures. J. Gerontol. 2017, 62, 744-751. [CrossRef]

5. Sugiyama, T.; Torio, T.; Sato, T.; Matsumoto, M.; Kim, Y.T.; Oda, H. Improvement of skeletal fragility by teriparatide in adult osteoporosis patients: A novel mechanostat-based hypothesis for bone quality. Front. Endocrinol. 2015, 6, 6. [CrossRef] [PubMed]

6. Edwards, M.H.; Dennison, E.M.; Aihie, S.A.; Fielding, R.; Cooper, C. Osteoporosis and sarcopenia in older age. Bone 2015, 80, 126-130. [CrossRef] [PubMed]

7. Avenell, A.; Handoll, H.H. Nutritional supplementation for hip fracture aftercare in older people. Int. J. Older People Nurs. 2011, 6, 315-317.

8. Donell, S.; Ryder, J.J. Bone morphogenetic protein (BMP) for fracture healing in adults. Cochrane Database Syst. Rev. 2010, 65. [CrossRef]

9. Bischoff-Ferrari, H.A.; Willett, W.C.; Orav, E.J.; Lips, P.; Meunier, P.J.; Lyons, R.A.; Flicker, L.; Wark, J.; Jackson, R.D.; Cauley, J.A. A pooled analysis of vitamin D dose requirements for fracture prevention. N. Engl. J. Med. 2012, 367, 40-49. [CrossRef] [PubMed]

10. Badescu, L.; Badulescu, O.; Badescu, M.; Ciocoiu, M. Mechanism by Sambucus nigra Extract Improves Bone Mineral Density in Experimental Diabetes. Evid.-Based Complement. Altern. Med. 2012, 2012. [CrossRef] [PubMed]

11. Wang, Z.Y.; Han, H.; Yang, B.Y.; Xia, Y.G.; Kuang, H.X. Two new iridoid glycosides from the root barks of Sambucus williamsii Hance. Molecules 2012, 17, 3869-3874. [CrossRef] [PubMed]

12. Zhang, K.; Ding, Y.; Kou, Z.; Dong, L.; Guo, Y.; Zhu, J. Researching Progress in Chemical Constituents and Biological Activity of Sambucus Williamsii Hance. Mod. Chin. Med. 2014, 10, 870-876.

13. Hu, N.; Ren, S.; Li, W.; Zhang, T.; Zhao, C. Morroniside promotes bone marrow mesenchymal stem cell proliferation in rats. Mol. Med. Rep. 2013, 7, 1565-1570. [CrossRef] [PubMed]

14. Hua, H.; Yang, B.; Xia, Y.; Wang, Q.; Kuang, H. Pharmacological Mechanism of Sambucus williamsii Hance in Promoting Fracture Healing. China Pharm. 2013, 16, 482-485.

15. Hua, H.; Yang, B.Y.; Liu, Y.; Xia, Y.G.; Wang, Q.H. Promotion of Sambucus williamsii root barks on fracture healing. Chin. Tradit. Herb. Drugs 2013, 44, 1957-1961. 
16. Yang, B.; Lin, X.; Yang, C.; Tan, J.; Li, W.; Kuang, H. Sambucus Williamsii Hance Promotes MC3T3-E1 Cells Proliferation and Differentiation via BMP-2/Smad/p38/JNK/Runx2 Signaling Pathway. Phytother. Res. 2015, 29, 1692-1699. [CrossRef] [PubMed]

17. Park, C.H.; Yamabe, N.; Noh, J.S.; Kang, K.S.; Tanaka, T.; Yokozawa, T. The beneficial effects of morroniside on the inflammatory response and lipid metabolism in the liver of $\mathrm{db} / \mathrm{db}$ mice. Biol. Pharm. Bull. 2009, 32, 1734-1740. [CrossRef] [PubMed]

18. Zhu, J.; Xu, K.; Zhang, X.; Cao, J.; Jia, Z.; Yang, R.; Ma, C.; Chen, C.; Zhang, T.; Yan, Z. Studies on the regulation of lipid metabolism and its mechanism of the iridoids rich fraction in Valeriana jatamansi Jones. Biomed. Pharmacother. 2016, 84, 1891-1898. [CrossRef] [PubMed]

19. Hui-Hua, Q.U.; Zhang, G.L.; Zhao, Y.; Wan, F.; Jia-Yang, S.; Wang, Y.; Kong, H.; Wang, Q.G. Synthesis and identification of artificial antigen of geniposide. J. Beijing Univ. Tradit. Chin. Med. 2013, 36, 387-392.

20. Fan, H.; Peng, J.; Hamann, M.T.; Hu, J.F. Lamellarins and Related Pyrrole-Derived Alkaloids from Marine Organisms. Chem. Rev. 2008, 39, 264-287. [CrossRef] [PubMed]

21. Toxqui, L.; Vaquero, M.P. Chronic iron deficiency as an emerging risk factor for osteoporosis: A hypothesis. Nutrients 2015, 7, 2324-2344. [CrossRef] [PubMed]

22. Xiao, W.; Hu, Z.; Li, T.; Li, J. Bone fracture healing is delayed in splenectomic rats. Life Sci. 2016, $173,55-61$. [CrossRef] [PubMed]

23. Ibrahim, N.I.; Mohamed, N.; Soelaiman, I.N.; Shuid, A.N. The Effects of Targeted Deliveries of Lovastatin and Tocotrienol on Ossification-Related Gene Expressions in Fracture Healing in an Osteoporosis Rat Model. Int. J. Environ. Res. Public Health 2015, 12, 12958-12976. [CrossRef] [PubMed]

24. Xue, S.; Ding, K.; Liu, J. Color forming property of derivatives and modificacion products of natural iridoids with methylamine. J. Am. Leather Chem. Assoc. 2015, 110, 1-6.

25. Sunghwa, F.; Sakurai, H.; Saiki, I.; Koketsu, M. Iodine-catalyzed etherification of morroniside. Chem. Pharm. Bull. 2009, 40, 112-115. [CrossRef]

26. Endo, T.; Taguchi, H. Study on the constituents of Cornus officinalis Sieb. et Zucc. Yakugaku Zasshi J. Pharm. Soc. Jpn. 1973, 93, 30-32. [CrossRef]

27. Bennasar, M.L.; Roca, T.; Monerris, M. Total synthesis of the proposed structures of indole alkaloids lyaline and lyadine. J. Org. Chem. 2004, 69, 752-756. [CrossRef] [PubMed]

Sample Availability: Samples of the compounds are not available from the authors.

(C) 2018 by the authors. Licensee MDPI, Basel, Switzerland. This article is an open access article distributed under the terms and conditions of the Creative Commons Attribution (CC BY) license (http://creativecommons.org/licenses/by/4.0/). 